\title{
PENGARUH STRUKTUR MODAL, LIKUIDITAS DAN UKURAN PERUSAHAAN TERHADAP KINERJA KEUANGAN PERUSAHAAN
}

\author{
Amelia Harsono dan Ary Satria Pamungkas \\ Program Studi Manajemen Fakultas Ekonomi \& Bisnis \\ Universitas Tarumanagara \\ Email : amelia.rachel1998@gmail.com
}

\begin{abstract}
The purpose of this research is to analyze effect of capital structure, liquidity, and firm size on the firms financial performance listed on the Indonesia Stock Exchange (IDX). This research was analyzed using panel data regression with eighty-five companies in the 2014-2018 period, generate four hundred twenty-five data observations. The research used purposive sampling to get the sample. The data used is secondary data from company financial statement data that obtained from Indonesia Stock Exchange (IDX), then its tabulated using Microsoft Excel 2016 and analyzed using Eviews-10. The results of this study indicate that the size of the company affects the financial performance of the company. However, capital structure and liquidity do not affect the company's financial performance.
\end{abstract}

Keywords: Capital Structure, Liquidity, Company Size, Firms Financial Performance

\begin{abstract}
Abstrak: Tujuan dari penelitian ini untuk melihat pengaruh struktur modal, likuiditas dan ukuran perusahaan terhadap kinerja keuangan perusahaan yang terdaftar pada Bursa Efek Indonesia (BEI). Penelitian ini di analisis menggunakan alat regresi data panel dengan delapan puluh lima perusahaan pada periode 2014-2018, menghasilkan empat ratus dua puluh lima data observasi. Teknik pengambilan sampel dalam penelitian ini menggunakan purposive sampling. Data yang digunakan berupa data sekunder yaitu laporan keuangan yang didapat dari Bursa Efek Indonesia (BEI), kemudian ditabulasi dengan Microsoft Excel 2016 dan dianalisis dengan menggunakan aplikasi Eviews 10. Hasil penelitian ini menunjukkan bahwa ukuran perusahaan berpengaruh pada kinerja keuangan perusahaan. Tetapi, struktur modal dan likuiditas tidak berpengaruh terhadap kinerja keuangan perusahaan.
\end{abstract}

Kata Kunci : Struktur Modal, Likuiditas, Ukuran Perusahaan, Kinerja Keuangan Perusahaan

\section{LATAR BELAKANG}

Pesatnya perkembangan dunia bisnis pada saat ini, yang dapat dilihat dari munculnya berbagai perusahaan pesaing dengan keunggulan masing-masing membuat setiap perusahaan harus terus melakukan perubahan dan pembaharuan. Hal ini membuat kompetisi dalam dunia bisnis terus bergerak dan mengalami dinamika perubahan yang sangat cepat. Setiap perusahaan akan terus berlomba-lomba untuk meningkatkan dan memaksimalkan laba serta keuntunganya masing-masing.

Memaksimalkan nilai dan memberi nilai tambah perusahaan terhadap asset yang dimiliki stakeholder. Nilai perusahaan merupakan persepsi stakeholder atau investor atas tingkat keberhasilan perusahaan atau sering juga dikaitkan dengan harga saham. Laba atau keuntungan perusahaan adalah salah satu bentuk kinerja keuangan suatu perusahaan, semakin tinggi laba atau keuntungan sebuah perusahaan maka kinerja perusahaan tersebut akan dianggap semakin baik pula. Selanjutnya ketika laba sudah maksimal tentunya akan berdampak pada kemakmuran pemilik perusahaan atau modal sehingga mengakibatkan 
peningkatan pada nilai perusahaan (Brigham \& Houston, 2011). Sehingga berdasarkan penjelasan diatas dapat disimpulkan bahwa tujuan utama perusahaan adalah untuk meningkatkan kemakmuran pemilik perusahaan.

Untuk mencapai tujuan tersebut, maka manajemen perusahaan akan mempertimbangkan dengan hati-hati setiap keputusan yang diambil supaya dapat mengarah pada peningkatan kemakmuran pemilik perusahaan. Hal ini menunjukkan kondisi keuangan perusahaan yang baik yang dipengaruhi oleh beberapa faktor seperti keputusan manajemen. Dikarenakan oleh sifatnya yang kompleks sehingga dalam usaha peningkantanya akan menyangkut efektivitas pemanfaatan modal serta efisiensi kegiatan operasional perusahaan.

Kenaikan laba akan menghasilkan hubungan positif atas kenaikan harga saham suatu perusahaan dalam jangka panjang. Dengan demikian, dapat dinyatakan bahwa informasi laba atau rugi dapat mempengaruhi harga saham. Secara sederhana, harga saham dipengaruhi oleh laba perusahaan, laba perusahaan tercantum dalam laporan keuangan. Kondisi laba atau rugi perusahaan tadi merupakan salah satu bentuk kinerja perusahaan yang paling mudah dideteksi oleh para stakeholder perusahaan.

Besarnya angka pertumbuhan profitabilitas searah dengan semakin baiknya nilai dari prospek perusahaan ke depannya. Kemudian besarnya angka profitabilitas akan merangsang para stakeholders untuk menilai kemampuan perusahaan dalam hal tingkat pengembalian atas investasi dan penjualan.

Kegiatan operasional perusahaan dalam rangka meningkatkan kinerja keuangan perusahaan tidak dapat dilepaskan dari dana perusahaan. Dalam memenuhi kebutuhan akan dana, maka perusahaan dapat menggunakan sumber pendanaan internal atau sumber pendanaan eksternal. Sumber dana internal adalah sumber pendanaan yang berasal dari dalam perusahaan itu sendiri seperti laba ditahan. Sedangkan sumber dana eksternal adalah sumber dana yang berasal dari luar yang berupa pinjaman dari pihak kreditur maupun dari pihak investor. Biasanya sumber dana eksternal digunakan oleh perusahaan jika perusahaan tidak dapat memenuhi kebutuhan pendanaanya secara internal.

\section{KAJIAN TEORI}

Teori yang digunakan dalam penelitian ini yaitu agency theory. Jensen dan Meckling (1976) menjelaskan hubungan keagenan sebagai hubungan yang timbul karena adanya perjanjian yang dilakukan antara pemilik perusahaan atau pemegang saham yang menggunakan agen untuk melakukan jasa yang menjadi kepentingan pemilik, secara tidak langsung dalam hal ini terjadi pemisahan kepemilikan dan pengendalian perusahaan. Teori keagenan adalah desain perjanjian yang dibuat untuk memberikan motivasi agen agar bertindak sesuai dengan kepentingan prinsipal ketika kepentingan agen bertolak belakang dengan prinsipal (Scott, 2012). Teori Agensi mengidentifikasikan adanya pihak-pihak dalam perusahaan yang memiliki beberapa kepentingan untuk mencapai tujuan dalam perusahaan. Teori tersebut muncul karena adanya hubungan antara prinsipal dan agen.

Menurut Fahmi (2015) kinerja keuangan adalah suatu analisis yang dilakukan untuk melihat sejauh mana suatu perusahaan telah melaksanakan dengan menggunakan aturanaturan pelaksanaan keuangan secara baik dan benar. Kinerja perusahaan merupakan suatu gambaran tentang kondisi keuangan suatu perusahaan yang dianalisis dengan alat-alat analisis keuangan, sehingga dapat diketahui mengenai baik buruknya keadaan keuangan suatu perusahaan yang mencerminkan prestasi kerja dalam periode tertentu. Hal ini sangat penting agar sumber daya digunakan secara optimal dalam menghadapi perubahan lingkungan.

Penilaian kinerja keuangan merupakan salah satu cara yang dapat dilakukan oleh pihak manajemen agar dapat memenuhi kewajibannya terhadap para penyandang dana dan juga untuk mencapai tujuan yang telah ditetapkan oleh perusahaan. 
Struktur modal merupakan gambaran dari bentuk proporsi finansial perusahaan yaitu antara modal yang dimiliki yang bersumber dari hutang jangka panjang (long-term liabilities) dan modal sendiri (shareholders equity) yang menjadi sumber pembiayaan suatu perusahaan (Fahmi, 2015). Sudana (2011) menyatakan bahwa Struktur Modal adalah pembelanjaan jangka panjang suatu perusahaan yang diukur dengan perbandingan utang jangka panjang dengan modal sendiri. Struktur modal (capital structure) merupakan bauran tertentu dari utang jangka panjang dan ekuitas yang digunakan perusahaan untuk mendanai kegiatan operasionalnya (Ross et al, 2015).

Menurut Subramanyan (2012), likuiditas adalah kemampuan perusahaan untuk memenuhi kewajiban finansialnya yang harus segera dipenuhi. Menurut Kasmir (2016) perhitungan rasio likuiditas ini cukup memberikan manfaat bagi berbagai pihak yang berkepentingan terhadap perusahaan baik pihak dalam maupun pihak luar perusahaan. Oleh karena itu, perhitungan rasio likuiditas tidak hanya berguna bagi perusahaan, namun juga bagi pihak luar perusahaan.

Ukuran Perusahaan merupakan salah satu faktor yang dipertimbangkan dalam menentukan berapa besar kebijakan atau keputusan pendanaan (struktur modal) dalam memenuhi skala besar kecilnya suatu perusahan. Salah satu tolak ukur yang menunjukan besar kecilnya suatu perusahaan adalah total assets yang dimiliki perusahan tersebut. Jika semakin besar perusahaan maka semakin besar pula dana yang dikeluarkan (Gitman, 2012). Selain itu, ukuran perusahaan yang semkian besar akan semakin memudahkan perusahaan untuk memperoleh sumber pendanaan baik yang bersifat internal maupun eksternal.

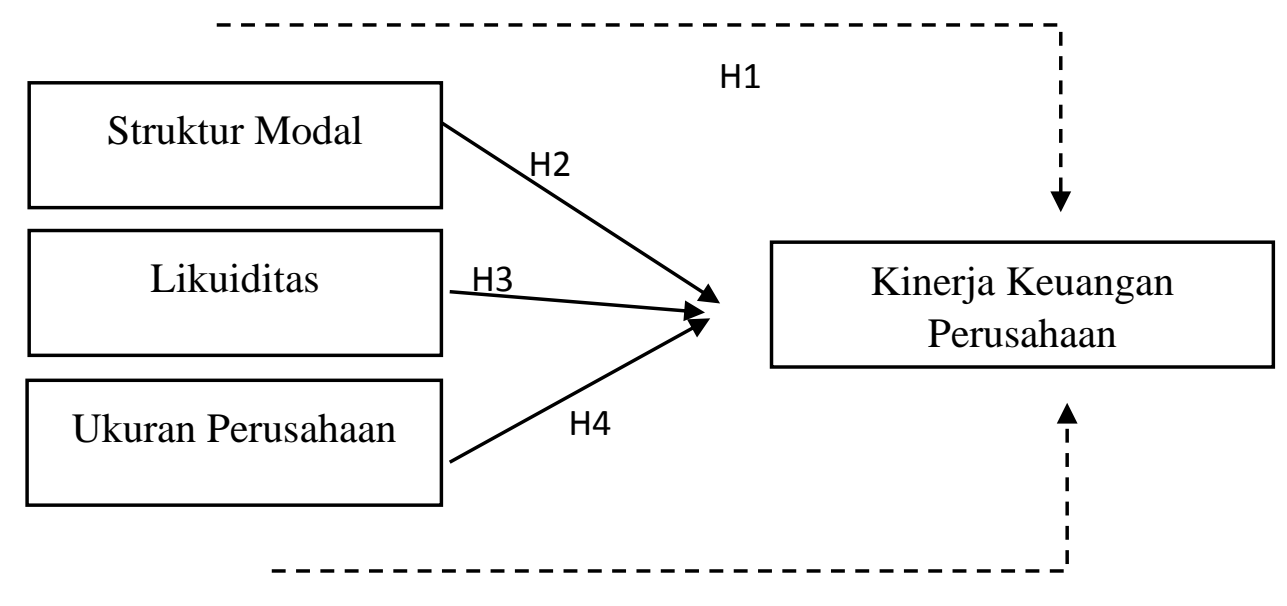

Gambar 1. Kerangka Pemikiran

Berdasarkan kerangka pemikiran di atas dapat disusun hipotesis sebagai berikut:

H1 : Terdapat pengaruh Struktur Modal, Likuiditas dan Ukuran Perusahaan terhadap Kinerja

Keuangan Perusahaan

H2 : Terdapat pengaruh Struktur Modal terhadap Kinerja Keuangan Perusahaan

H3 : Terdapat pengaruh Likuiditas terhadap Kinerja Keuangan Perusahaan

H4 : Terdapat pengaruh Ukuran Perusahaan terhadap Kinerja Keuangan Perusahaan

\section{METODOLOGI}

Penelitian ini menggunakan subyek dari perusahaan manufaktur yang terdaftar pada Bursa Efek Indonesia (BEI). Untuk melihat pengaruh terhadap kinerja keuangan perusahaan, 
maka digunakan variabel struktur modal, likuiditas dan ukuran perusahaan. Jumlah data yang diobservasi sebanyak 85 perusahaan dengan periode 2014-2018. Dalam penelitian ini kinerja perusahaan diukur dengan ROA (Return on Asset), struktur modal menggunakan LDER (Long Term Debt to Equity), likuiditas menggunakan current ratio, sedangkan ukuran perusahaan menggunakan logaritma alami dari total asset. Metode pemilihan sampel yang digunakan purposive sampling. Dalam penelitian ini uji statistik yang digunakan adalah Uji Chow, Uji Hausman, Fixed Effect Model, Analisis Regresi Linear Berganda, Uji Statistik t, dan Koefisien Determinasi (Adjusted R Square).

\section{HASIL ANALISIS DATA}

Dalam penelitian ini menggunakan beberapa uji analisis data, yaitu Uji Chow, Uji Hausman, Fixed Effect Model, Analisis Regresi Linear Berganda, Uji Statistik t, dan Koefisien Determinasi (Adjusted R Square).

Tabel 1. Hasil Uji Chow

\begin{tabular}{lccc}
\hline \multicolumn{1}{c}{ Effect Test } & Statistics & d.f & Prob. \\
\hline Cross-section F & 5.7981 & $(84,337)$ & 0.0000 \\
Cross-section Chi-square & 380.0069 & 84 & 0.0000 \\
\hline
\end{tabular}

\section{Uji Chow}

Berdasarkan hasil uji chow diperoleh nilai probabilitas cross-section F sebesar 0,0000 dimana lebih kecil dari $\alpha$ sebesar 0,05 sehingga dapat disimpulkan bahwa fixed effect menjadi model yang terpilih untuk digunakan. Namum tidak berhenti di sini, perlu dilakukan uji selanjutnya yaitu uji hausman. Uji hausman digunakan untuk memilih antara random effect atau fixed effect model.

Tabel 2. Hasil Uji Hausman

\begin{tabular}{cccc}
\hline Test Summary & Chi-square Statistics & Chi-square d.f & Prob. \\
\hline Cross-section random & 306.575 & 3 & 0.0000 \\
\hline
\end{tabular}

\section{Uji Hausman}

Berdasarkan hasil uji hausman di atas, maka diperoleh nilai probabilitas cross section random sebesar 0,0000. Nilai tersebut lebih kecil dari $\alpha$ sebesar 0,05, sehingga dapat disimpulkan fixed effect model menjadi model yang digunakan untuk estimasi data panel.

Tabel 3. Hasil Regresi Data Panel Menggunakan Fixed Effect Model

\begin{tabular}{llll}
\hline Variabel & Coefficient & t-Statistics & Prob. \\
\hline Konstanta & 79.2827 & 18.5315 & 0.0000 \\
LDER & $-3.48 \times 10^{-5}$ & -0.0056 & 0.9955 \\
CR & 0.0045 & 0.1389 & 0.8896 \\
SIZE & -2.7665 & -18.5069 & 0.0000 \\
\hline R-squared & 0.6024 & F-statistic & 5.87 \\
Adjusted R-squared & 0.4998 & Prob (F-statistic) & 0.0000 \\
\hline
\end{tabular}


Berdasarkan hasil estimasi untuk model regresi data panel model fixed effect didapatkan nilai probabilitas (F-statistic) sebesar 0,0000 dimana lebih kecil dari $\alpha$ yaitu 0,05 yang berarti terdapat pengaruh Struktur Modal, Likuiditas dan Ukuran Perusahaan.

\section{Uji Statistik t}

Selanjutnya merupakan uji statistic $t$ untuk melihat seberapa jauh pengaruh satu variabel independent secara individual dapat menjelaskan variasi variabel dependen. Dengan melihat Tabel 3 pada bagian probabilitas dan koefisien dapat disusun hipotesis sebagai berikut :

a. Hipotesis pengaruh struktur modal terhadap kinerja keuangan perusahaan

H2 : Terdapat pengaruh Struktur Modal terhadap Kinerja Keuangan Perusahaan.

Koefisien regresi variabel Struktur Modal (LDER) sebesar -3,48 x 10 $0^{-5}$ artinya Struktur Modal (LDER) mempunyai arah yang negative terhadap ROA. Setiap peningkatan Struktur Modal (LDER) sebesar 1 satuan, maka akan menurunkan kinerja keuangan perusahaan (ROA) sebesar $-3,48 \times 10^{-5}$ satuan, dengan asumsi nilai dari variabel independent yang lain tetap. Variabel Struktur Modal (LDER) memiliki nilai probabilitas sebesar 0,9955 yang lebih besar dari $\alpha$ sebesar 0,05 sehingga $\mathrm{H}_{0}$ tidak ditolak atau dapat disimpulkan tidak terdapat pengaruh Struktur Modal terhadap Kinerja Keuangan Perusahaan.

b. Hipotesis pengaruh likuiditas terhadap kinerja keuangan perusahaan

H3: Terdapat pengaruh Likuiditas terhadap Kinerja Keuangan Perusahaan.

Koefisien regresi variabel Likuiditas (CR) sebesar 0,0045 artinya Likuiditas (CR) mempunyai arah yang positif terhadap ROA. Setiap peningkatan Likuiditas (CR) sebesar 1 satuan, maka akan meningkatkan kinerja keuangan perusahaan (ROA) sebesar 0,0045 satuan, dengan asumsi nilai dari variabel independent yang lain tetap. Variabel Likuiditas (CR) memiliki nilai probabilitas sebesar 0,8896 yang lebih besar dari $\alpha$ sebesar 0,05 sehingga $\mathrm{H}_{0}$ tidak ditolak atau dapat disimpulkan tidak terdapat pengaruh Likuiditas terhadap Kinerja Keuangan Perusahaan.

c. Hipotesis pengaruh ukuran perusahaan terhadap kinerja keuangan perusahaan

H4 : Terdapat pengaruh Ukuran Perusahaan terhadap Kinerja Keuangan Perusahaan.

Koefisien regresi variabel Ukuran Perusahaan (SIZE) sebesar -2,7665 artinya Ukuran Perusahaan (SIZE) mempunyai arah yang negative terhadap ROA. Setiap peningkatan Ukuran Perusahaan (SIZE) sebesar 1 satuan, maka akan menurunkan kinerja keuangan perusahaan (ROA) sebesar 2,7665 satuan, dengan asumsi nilai dari variabel independent yang lain tetap. Variabel Ukuran Perusahaan (SIZE) memiliki nilai probabilitas sebesar 0,0000 yang lebih kecil dari $\alpha$ sebesar 0,05 sehingga $\mathrm{H} 0$ ditolak atau dapat disimpulkan terdapat pengaruh Ukuran Perusahaan terhadap Kinerja Keuangan Perusahaan.

\section{Uji Koefisien Determinasi (Adjusted R Square)}

Berdasarkan Tabel 3, R-squared yang diperoleh sebesar 0,6024 sehingga dapat disimpulkan variasi keragaman variabel Kinerja Keuangan Perusahaan (ROA) mampu dijelaskan oleh variabel struktur modal (LDER), likuiditas (CR) dan ukuran perusahaan 
(SIZE) sebesar 60,24\% sedangkan sisanya sebesar 39,76\% dijelaskan oleh variabel lain di luar penelitian ini.

\section{DISKUSI}

Jika dilihat dari hasil uji t pada tabel 3 menunjukkan bawa struktur modal tidak berpengaruh terhadap kinerja keuangan perusahaan. Berdasarkan teori struktur modal, apabila posisi struktur modal berada di atas target struktur modal optimalnya, maka setiap pertambahan utang akan menurunkan kinerja keuangan. Penentuan target struktur modal optimal adalah salah satu dari tugas utama manajemen perusahaan. Struktur modal adalah proporsi pendanaan dengan utang (debt financing) perusahaan, yaitu rasio laverage (pengungkit) perusahaan. Dengan demikian, utang adalah unsur dari struktur modal perusahaan.

Dilihat dari hasil uji t sebelumnya, menunjukkan bahwa likuiditas tidak berpengaruh terhadap kinerja keuanhan perusahaan. Likuiditas berhubungan dengan masalah kemampuan perusahaan untuk memenuhi kewajiban finansialnya yang harus segera dipenuhi. Jumlah alat likuid yang dimiliki oleh perusahaan pada suatu saat merupakan kekuatan membayar dari perusahaan tersebut. Semakin tinggi current ratio suatu perusahaan berarti semakin kecil resiko kegagalan perusahaan dalam memenuhi kewajiban jangka pendeknya. Likuiditas berbanding searah dengan profitabilitas yang dilaporkan. Dimana jika likuiditas meningkat maka profitabilitas perusahaan juga akan meningkat. Hal ini terjadi karena naiknya aktiva lancar yang dimiliki perusahaan lebih besar dari pada utang lancarnya. Dimana aktiva lancar biasanya dipengaruhi oleh salah satu faktor yaitu persediaan. Kurangnya persediaan dikarenakan dana pihak ketiga atau modal perusahaan yang kurang sehingga proses produksi perusahaan mengalami penurunan dan penurunan laba perusahaan. Sehingga mengakibatkan Profitabilitas perusahaan menurun.

Berdasarkan hasil uji t pada tabel 3, menunjukkan bahwa ukuran perusahaan berpengaruh terhadap kinerja keuangan perusahaan. Ukuran perusahaan merupakan ukuran atau besarnya aset yang dimiliki oleh sebuah perusahaan yang ditunjukkan oleh natural logaritma dari total aktiva.

\section{PENUTUP}

Berdasarkan pembahasan yang sudah dilakukan sebelumnya maka dapat ditarik kesimpulan sebagai berikut :

1. Terdapat pengaruh Struktur Modal, Likuiditas dan Ukuran Perusahaan terhadap Kinerja Keuangan Perusahaan.

2. Tidak terdapat pengaruh Struktur Modal terhadap Kinerja Keuangan Perusahaan.

3. Tidak terdapat pengaruh Likuiditas terhadap Kinerja Keuangan Perusahaan.

4. Terdapat pengaruh Ukuran Perusahaan terhadap Kinerja Keuangan Perusahaan.

\section{SARAN}

Dalam penyusunan penelitian ini masih jauh dari sempurna, maka terdapat beberapa saran yang dapat diberikan :

1. Pada penelitian ini, kinerja keuangan perusahaan hanya dijelaskan melalui 3 variabel independen yaitu struktur modal, likuiditas dan ukuran perusahaan. Disarankan 
untuk penelitian selanjutnya agar menambah atau menggunakan variabel independen lain yang mungkin dapat menjelaskan kinerja keuangan perusahaan. Variabel independen lain yang dapat menjelaskan kinerja keuangan perusahaan yaitu, good corporate governance (GCG), executive's compencation, dan corporate social responsibility.

2. Subjek pada penelitian ini hanya perusahaan manufaktur yang terdaftar pada Bursa Efek Indonesia, disarankan kepada penelitian selanjutnya agar menggunakan perusahaan dari sektor lainnya sebagai sampel penelitian.

3. Kepada para manajemen disarankan agar memperhatikan variabel-variabel yang terkait dengan kinerja keuangan perusahaan, sehingga dapat memperhatikan variabel-variabel pada penelitian ini terutama yang memiliki pengaruh signifikan terhadap kinerja keuangan perusahaan.

\section{Daftar Pustaka}

Agus Widarjono. 2018. Analisis Statistika Multivariat Terapan. Edisi pertama. Yogyakarta: UPP STIM YKPN

Akenga, Grace. 2015. Effect of Liquidity on Financial Performance of Firms Listed at the Nairobi Securities Exchange, Kenya. International Journal of Science and Research (IJSR) ISSN (Online): 2319-7064

Baridwan, Salno. 2000. Analisis Perataan Penghasilan (Income Smoothing): Faktorfaktor yang Mempengaruhi dan Kaitannya dengan Kinerja Saham Perusahaan Publik di Indonesia,"Jurnal Riset Akuntansi Indonesia, No. 1, Vol. 3.

Brigham, Eugene F. dan Houston, Joel F. 2011. Dasar-dasar Manajemen Keuangan Terjemahan. Edisi 10. Jakarta: Salemba Empat.

Dahlia, Cindy. 2018. Pengaruh Struktur Modal, Ukuran Perusahaan, Likuiditas Terhadap Kinerja Keuangan Yang Dimoderasi Inflasi. Jurnal Muara Ilmu Ekonomi dan Bisnis ISSN 2579-6224 (Versi Cetak) Vol. 2, No. 2, Oktober 2018: hlm 494-502 ISSN-L 2579-6232 (Versi Elektronik)

Demirgüneş, Kartal. 2016/ The Effect of Liquidity on Financial Performance: Evidence from Turkish Retail Industry. International Journal of Economics and Finance; Vol. 8, No. 4; 2016 ISSN 1916-971X E-ISSN 1916-9728

Fahmi, Irham. 2015. Pengantar manajemen keuangan, teori dan soal. Bandung: Alfabeta

Fajaryani, Ni Luh Gede Sri. 2018. Struktur Modal, Likuiditas, Dan Ukuran Perusahaan Terhadap Kinerja Keuangan Perusahaan. Jurnal Riset Akuntansi Kontemporer Volume 10, No 2, Oktober 2018, Hal. 74-79 ISSN 2088-5091 (print) 2597-6826 (online)

Ghozali, I. 2016. Aplikasi Analisis Multivariate dengan Program IBM SPSS 19. 5 ed. Semarang: Badan Penerbitan Universitas Diponegoro.

Gitman, L.J.; Zutter, C.J. 2012. Principles of Managerial Finance. 13e. Boston: Pearson.

Harahap, Sofyan Syafri. 2015. Analisis Kritis atas Laporan Keuangan. Edisi 1-10. Jakarta: Rajawali Pers.

Hartono, J. (2014). Metode Penelitian Bisnis (Salah Kaprah dan PengalamanPengalaman) (Vol. 6). Yogyakarta, Indonesia: BPFE-YOGYAKARTA

Hastuti, Tri. 2017. Pengaruh Struktur Modal Dan Ukuran Perusahaan Terhadap Kinerja Keuangan Pada Perusahaan Tekstil Dan Garmen Yang Terdaftar Di Bursa Efek Indonesia Periode 2010-2014. JOM FISIP Vol. 4 No. 2 
Kasmir. 2016. Analisis Laporan Keuangan, Edisi kesatu, cetakan kedelapan. Jakarta: PT. Raja Grafindo Persada.

Keown, Arthur J. David F. Scott, Jr, John D. Martin, J. William Petty. 2011. Dasar-Dasar Manajemen Keuangan. Edisi Satu. Jakarta: Salemba Empat

Oktapiyani, Desi. 2009. Pengaruh Penerapan Corporate Governance Terhadap Likuiditas Perbankan Nasional. Skripsi. Fakultas Ekonomi Universitas Diponegoro Semarang. 